\title{
The Reaction of Penicillin with Proteins
}

\author{
By PATRICK H. CORRAN* and STEPHEN G. WALEY \\ Sir William Dunn School of Pathology, University of Oxford, \\ South Parks Road, Oxford OX1 3RE, U.K.
}

(Received 2 December 1974)

\begin{abstract}
The mode of reaction of benzylpenicillin with two proteins was studied, with particular reference to the allergenicity of penicillin. These reactions, with pig insulin, and with hen's-egg-white lysozyme, were carried out in neutral solution at $37^{\circ} \mathrm{C}$. High concentrations of penicillin are needed to label the proteins, owing to concurrent hydrolysis of penicillin. Evidence has been obtained that the penicillin-reactive sites on the insulin molecule are the $\alpha$-amino group at the $N$-terminus of the A chain and the $\varepsilon$-amino group of the lysine residue; whereas a site of reaction with lysozyme appears to be the $\varepsilon$-amino group of lysine-116.
\end{abstract}

Although penicillin is virtually non-toxic, a few people react severely, even to a small dose (Idsoe et al., 1968). The most dangerous reaction is anaphylactic shock. This (and nearly all other untoward reactions) is a manifestation of an allergic response, a consequence of an antigen-antibody reaction occurring in a sensitized individual. The administration of penicillin always causes the production of antibodies, but although penicillin is immunogenic to all it is allergenic to only a few. Penicillin is assumed to give rise to determinants by virtue of reacting with more than one site in one or more proteins (de Weck \& Schneider, 1969). The major antigenic determinant is the penicilloyl group (I) that arises from cleavage of the $\beta$-lactam ring in penicillin (II).<smiles>[R]C(=O)CC(NC([R])C([R])=O)SC(C)(C)C(=O)[O-]</smiles>

(I)

The major determinant (I), once thought to be formed in vivo via penicillenates, is now regarded as being formed directly (de Weck et al., 1968). But, although the reaction of penicillin with low-molecular-weight compounds in neutral solution has been

* Present address: National Institute for Biological Standards and Control, Holly Hill, Hampstead, London NW3 6RB, U.K. described (Schneider \& de Weck, 1968), the nature of the reaction with proteins in neutral solution is quite unknown. Proteins do react with penicillin in neutral solution (Batchelor et al., 1965), as judged by the penamaldyl assay for the penicilloyl group (Levine, 1962), but the sites of reaction were not ascertained. The most rapid reaction with low-molecular-weight compounds occurs when a thiol group is present, and penicillin reacts with cysteine approx. $10^{4}$ times as fast as with alanine (Nakken et al., 1960). Whether there is a high-molecular-weight counterpart of this reaction is not known, and we were not able to test the reaction of penicillin with a protein having $N$-terminal cysteine (e.g. chicken liver glutamate dehydrogenase; Moon et al., 1973). If in fact penicillin has to react

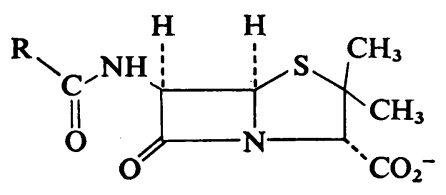

(II)

covalently with proteins to give rise to the antigenic determinants that are responsible for anaphylactic shock, this reaction must indeed be rapid; most anaphylactic reactions occur within a few minutes of injection of the penicillin (Idsoe et al., 1968).

The role of impurities in penicillin allergy is doubtful, as is the part that may be played by oligomers formed on storage (de Weck et al., 1968; Smith \& 
Marshall, 1971; Stewart, 1973). The major determinant (I) is generally supposed to arise from the reactions of penicillin with amino groups. We set out to test this view by identifying the sites of reaction with two well-characterized proteins, insulin and lysozyme. In the crystalline state, lysozyme forms a complex with phenoxymethylpenicillin (Johnson, 1967). The reactions were fairly selective, and efficient labelling demanded a high concentration of penicillin. This is because the time-scale for reaction (at $\mathrm{pH} 7.5,37^{\circ} \mathrm{C}$ ) is of the order of tens of hours, and the stability of penicillin on this time-scale is limited. Identification of the main sites of reaction in the two proteins has been achieved, and thus, to some extent, ideas on the formation of the penicilloyl determinant now rest on a firmer foundation. The main effort went into solving the difficult technical problems of isolating the penicilloyl peptides; it is notoriously difficult to assess yields in this kind of work.

\section{Materials and Methods}

\section{Materials}

Pig insulin (10 $\times$ crystallized) was from Novo Terapeutisk Laboratorium, Copenhagen, Denmark. It was freed from zinc by dissolving $73 \mathrm{mg}$ in $3 \mathrm{ml}$ of $2 \%(\mathrm{v} / \mathrm{v})$ acetic acid, treating with $7 \mathrm{mg}$ of EDTA (disodium salt) and then raising the $\mathrm{pH}$ to 5.4 (Sluyterman, 1955). The precipitated protein was collected, washed and dried. Hen's-egg-white lysozyme was from BDH Chemicals, Poole, Dorset, U.K. Potassium 6-phenyl[1-14 C]acetamidopenicillanate was from The Radiochemical Centre, Amersham, Bucks., U.K.; benzylpenicillin and cephalosporin $\mathrm{C}$ were from Glaxo Research Laboratories, Greenford, Middx., U.K. Trypsin (twice recrystallized) was from Worthington Biochemical Corp., Freehold, N.J., U.S.A. 'Protease type VI' was from Sigma (London) Chemical Co., Kingston-uponThames, Surrey, U.K., and is referred to below as Pronase.

\section{Methods}

Paper chromatography was carried out in solvent BAWP [butan-1-ol-acetic acid-water-pyridine (15:3:12:10, by vol.) (Waley \& Watson, 1953)] and paper electrophoresis as described by Corran \& Waley (1974). Peptides were detected and hydrolysed as described by Miller \& Waley (1971). Amino acid analysis was carried out with a Bio-Cal 100 analyser equipped with a high-sensitivity colorimeter. Liquid-scintillation counting was carried out as described by Browne \& Waley (1974).

When the standard procedures for the hydrolysis of peptides $\left(6 \mathrm{M}-\mathrm{HCl}\right.$ at $108^{\circ} \mathrm{C}$ for $16 \mathrm{~h}$ in evacuated tubes) were applied either to penicillin itself or to penicilloic acid or its amide the yield of ninhydrinpositive material (largely penicillamine) was less than
$5 \%$ (an average colour constant being used). Thus no peaks on the analyser from the penicilloyl moiety were detected on hydrolysis of small amounts of penicilloyl peptides.

Penicilloyl groups (in labelled proteins) were determined by the penamaldate assay (Schneider \& de Weck, 1966a). Protein was measured either by the micro biuret method (Leggett-Bailey, 1967) or by a variant of the biuret method in which $1.5 \mathrm{ml}$ of $1 \mathrm{M}$ $\mathrm{NaOH}$ followed by $50 \mu \mathrm{l}$ of $20 \%$ (w/v) $\mathrm{CuSO}_{4}$ was added to $0.6 \mathrm{ml}$ of sample solution and the $E_{560}$ of the supernatant determined. Standard curves were constructed with insulin or lysozyme.

Polyacrylamide gels were run in $50 \mathrm{~mm}$-sodium acetate-2mM-EDTA, pH6, 7 $\mathrm{M}$ in urea; the buffer in the electrode compartments lacked urea. Electrophoresis was for $4 \mathrm{~h}$ at $5 \mathrm{~mA}$ per tube and the origin was at the anode. Gels were stained with $1 \% \mathrm{Naph}$ thalene Black in $7 \%(\mathrm{v} / \mathrm{v})$ acetic acid, and destained with $7 \%(\mathrm{v} / \mathrm{v})$ acetic acid.

Reaction of benzylpenicillin with insulin. The potassium salt of benzylpenicillin $(150 \mathrm{mg}$, containing $10 \mu \mathrm{Ci}$ of potassium 6-phenyl[1-14 C]acetamidopenicillanate) and zinc-free pig insulin $(20 \mathrm{mg})$ were incubated in $2 \mathrm{ml}$ of $0.05 \mathrm{M}$-sodium phosphate, $\mathrm{pH} 7.4$, in a pH-stat (kept at $\mathrm{pH} 7.4$ ) for $24 \mathrm{~h}$ at $37^{\circ} \mathrm{C} ; 0.73 \mathrm{ml}$ of $0.2 \mathrm{M}$ $\mathrm{NaOH}$ was added during this time. The high-molecular-weight fraction was isolated by gel filtration on a column $(23 \mathrm{~cm}$ high $\times 1 \mathrm{~cm}$ diam.) of Sephadex G-25 in $1 \% \mathrm{NH}_{4} \mathrm{HCO}_{3}$; it comprised fractions $7-9$ and contained about $1 \%$ of the radioactivity in the reaction mixture (the fraction size was $1 \mathrm{ml}$ ). The disulphide bonds were reduced, and the thiol groups aminoethylated by adding to the high-molecularweight fraction $(3 \mathrm{ml})$ an equal volume of propan1-ol, and then $20 \mu \mathrm{l}$ of tributylphosphine and $10 \mu \mathrm{l}$ of ethyleneimine, and keeping the reaction mixture for $16 \mathrm{~h}$.

Excess of ethyleneimine was removed by bubbling $\mathrm{N}_{2}$ through the solution, which was then concentrated and the residue dissolved in $50 \%(\mathrm{v} / \mathrm{v})$ acetic acid; the high-molecular-weight fraction (eluted at $13-17 \mathrm{ml}$ ) was isolated by gel filtration in $50 \%$ acetic acid on a column $(26 \mathrm{~cm}$ high $\times 1.5 \mathrm{~cm}$ diam. $)$ of Sephadex G-25. The solvent was removed by concentration and then freeze-drying, and the residue, suspended in $0.7 \mathrm{ml}$ of $1 \% \mathrm{NH}_{4} \mathrm{HCO}_{3}$, was treated with $80 \mu \mathrm{g}$ of trypsin for $1.5 \mathrm{~h}$, and then $30 \mu \mathrm{g}$ more trypsin added. After $4 \mathrm{~h}$ digestion (in all) at $37^{\circ} \mathrm{C}$, the precipitate was removed and the solution submitted to paper electrophoresis (Fig. 1).

\section{Results}

Sites of reaction of penicillin with insulin

Benzylpenicillin (II, $\mathrm{R}=\mathrm{C}_{6} \mathrm{H}_{5} \mathrm{CH}_{2}$ ) was used in all the experiments described. The reaction mixture contained $200 \mathrm{~mm}$-penicillin and $1.73 \mathrm{~mm}$-insulin. 
The products were fractionated by gel filtration, and the high-molecular-weight fraction was treated with tributylphosphine and ethyleneimine to reduce the disulphide bonds and aminoethylate the thiol groups;

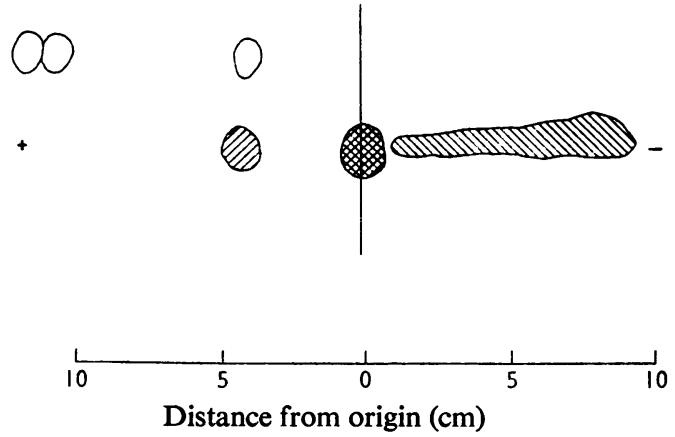

Fig. 1. Electrophoresis of tryptic digest of insulin treated with benzylpenicillin

Insulin and radioactive benzylpenicillin were incubated together at $\mathrm{pH} 7.4$ for $24 \mathrm{~h}$ at $37^{\circ} \mathrm{C}$. The isolation of the high-molecular-weight fraction and its treatment with trypsin are described in the Materials and Methods section. Paper electrophoresis was carried out at $\mathrm{pH} 6.5$ in pyridineacetic acid-water (25:1:225, by vol.) on Whatman no. $3 \mathrm{MM}$ paper, for $1 \mathrm{~h}$ at $2 \mathrm{kV}$. The unhatched spots are dye markers (Xylene Cyanol FF, Acid Fuchsin and Orange G, in order of increasing mobility). Hatching: ninhydrin-positive spots; radioactive spots. The 'neutral' spot, remaining at the origin, may contain adsorbed (possibly undigested) material. this can conveniently be done in one operation (MacLaren \& Sweetman, 1966; Rüegg \& Rudinger, 1974) (see the Materials and Methods section for experimental details). The protein was digested with trypsin and the digest fractionated by electrophoresis at pH6.5 (Fig. 1). There was an acidic radioactive ninhydrin-negative spot; this spot was absent from digests of (reduced and aminoethylated) insulin that had not been incubated with penicillin. The acidic radioactive peptide $\mathrm{IT}_{1}$ (Table 1) arises from the $N$ terminal region of the A chain by tryptic cleavage at $S$-aminoethylcysteine. The sequence in this region is: Gly-Ile-Val-Glu-Gln-Cys ... (Brown et al., 1955). Hence penicillin has reacted with the amino group of the $N$-terminal glycine residue. The neutral fraction, which was further fractionated by chromatography in solvent BAWP, contained some radioactivity, but no pure peptide was isolated.

Better yields of radioactive peptides were obtained from digests of labelled insulin with Pronase. There were two radioactive peptides (Table 1). One peptide had a high mobility $(-0.81)$, and was ninhydrinnegative (peptide $\mathrm{IP}_{1}$ ), and is the counterpart of the tryptic peptides $\mathrm{IT}_{1}$ and $\mathrm{IT}_{2}$; enzymic cleavage has occurred at glutamine- 5 here, as is shown by the high electrophoretic mobility. The presence of the penicilloyl group (I, $\mathrm{R}=\mathrm{C}_{6} \mathrm{H}_{5} \mathrm{CH}_{2}$ ) at the $N$-terminus gives the acylated pentapeptide a charge of -3 ; with a molecular weight of about 800 , the mobility of -0.81 is not unexpected (Offord, 1966).

The other radioactive peptide (peptide $\mathrm{IP}_{2}$ ) was further purified by electrophoresis at $\mathrm{pH} 4.5$;

\section{Table 1. Radioactive peptides obtained from reaction of $\left[{ }^{14} \mathrm{C}\right]$ penicillin with insulin}

Samples IT $\mathrm{IT}_{1}$ and $\mathrm{IT}_{2}$ were isolated after tryptic cleavage of reduced and $S$-aminoethylated insulin; they are derived from separate experiments. $S$-Aminoethylcysteine was present (but not measured) in the hydrolysate of peptide IT $_{1}$ and was not looked for in the hydrolysate of peptide IT 2 . Peptides IP ${ }_{1}$ and IP $\mathbf{I P}_{2}$ were isolated after Pronase digestion of insulin. After gel filtration the high-molecular-weight fraction $(3 \mathrm{ml})$ was treated with $0.2 \mathrm{mg}$ of Sigma proteinase type VI at $37^{\circ} \mathrm{C}$ for $18 \mathrm{~h}$. The freeze-dried residue was extracted with $0.2 \mathrm{ml}$ of $10 \%(\mathrm{v} / \mathrm{v})$ pyridine, and the supernatant solution, containing about half of the radioactivity of the high-molecular-weight fraction, was fractionated by electrophoresis at $\mathrm{pH}$ 6.5. The electrophoretic mobilities $(m)$ refer to pH6.5 and are relative to aspartic acid $(m=-1.00)$. The amino acid compositions are given as molar ratios. The ninhydrin colour refers to the initial colour with the cadmium reagent (Heilmann et al., 1957). The values in columns 4 and 6 are those calculated for residues 1-5 of the A chain and 27-29 of the B chain respectively.

(4)

\begin{tabular}{|c|c|c|c|c|c|c|c|c|}
\hline Amino acid & Peptide & ... & $\begin{array}{l}\text { (1) } \\
\mathrm{IT}_{1}\end{array}$ & $\begin{array}{l}(2) \\
\mathrm{IT}_{2}\end{array}$ & $\begin{array}{l}\text { (3) } \\
\text { IP }_{1}\end{array}$ & $\begin{array}{c}\text { (4) } \\
\text { Calc. for } \\
\text { A1-A5 }\end{array}$ & $\begin{array}{l}(5) \\
\mathbf{I P}_{2}\end{array}$ & $\begin{array}{c}\text { (6) } \\
\text { Calc. for } \\
\text { B27-B29 }\end{array}$ \\
\hline Thr & & & & & & & 0.8 & 1 \\
\hline Glu & & & 2.2 & 2.0 & 1.75 & 2 & & \\
\hline Pro & & & & & & & 1.1 & 1 \\
\hline Gly & & & 1.1 & 1.1 & 1.25 & 1 & & \\
\hline Val & & & 1.0 & 1.0 & 1.1 & 1 & & \\
\hline Ile & & & 0.7 & 0.9 & 0.9 & 1 & & \\
\hline Lys & & & & & & & 1.1 & 1 \\
\hline $\begin{array}{l}m \\
\text { Ninhydrin colour } \\
N \text {-Terminus }\end{array}$ & & & $\begin{array}{c}-0.48 \\
\text { Red }\end{array}$ & $\begin{array}{l}-0.5 \\
\text { Red }\end{array}$ & $\begin{array}{l}-0.81 \\
\text { None } \\
\text { None }\end{array}$ & & $\begin{array}{l}-0.51 \\
\text { Yellow } \\
\text { Thr }\end{array}$ & \\
\hline
\end{tabular}

Vol. 149 


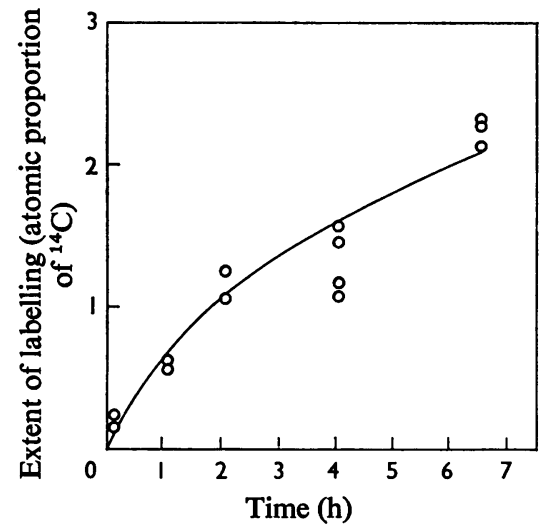

Fig. 2. Reaction of benzylpenicillin with insulin

6-Phenyl[1-14 C]acetamidopenicillanate $(0.4 \mathrm{M}$, containing $10 \mu \mathrm{Ci}$ of radioactivity) and pig insulin $(1.73 \mathrm{~mm})$ were incubated at $\mathrm{pH} 7.6$, in a pH-stat at $37^{\circ} \mathrm{C}$. Portions $(0.4 \mathrm{ml})$, withdrawn at intervals (Fig. 1), were fractionated by gel filtration on a column $(20 \mathrm{~cm}$ high $\times 1 \mathrm{~cm}$ diam.) of Sephadex G-25 in $1 \% \mathrm{NaHCO}_{3}$. Portions $(50 \mu \mathrm{l})$ of the $0.5 \mathrm{ml}$ fractions were taken for radioactivity counting and portions $(0.4 \mathrm{ml})$ for measurement of protein by the micro biuret method.

the composition and $N$-terminus (Table1) show that penicillin had reacted with the $\varepsilon$-amino group of lysine; residues $27-29$ in the B chain are: Thr-Pro-Lys.

\section{Course of reaction of penicillin with insulin}

The rate of reaction of penicillin with insulin was studied by carrying out gel filtration on samples withdrawn from the reaction mixture and determining the specific radioactivity of the protein. The results (Fig. 2) give some idea of the overall rate of reaction. The shape of the curve provides no evidence for preferential reaction at one of the two sites. Detailed analysis of the rates would demand separation of all the individual species at each timeinterval.

\section{Site of reaction of penicillin with lysozyme}

A preliminary experiment was carried out to see if the $N$-terminal amino group in lysozyme resembled that in insulin in reacting with penicillin. Lysozyme $(10 \mathrm{mg})$ was incubated with penicillin $(20 \mathrm{mg})$ in $0.5 \mathrm{ml}$ of $1 \% \mathrm{NH}_{4} \mathrm{HCO}_{3}$ for $16 \mathrm{~h}$ at $37^{\circ} \mathrm{C}$, and the protein precipitated with $5 \mathrm{ml}$ of acetone. The $N$-terminal amino acid was identified by reaction with dansyl chloride in the presence of sodium dodecyl sulphate (Gray, 1972), and an untreated sample of lysozyme was similarly treated. The samples gave indistinguishable results (bis-Dns-lysine, together with $O$-Dns- tyrosine and $\varepsilon$-Dns-lysine), so that there was no evidence for reaction of penicillin with the $N$-terminus of lysozyme.

Of the many other experiments aimed at characterizing the site of reaction two are now described.

Benzylpenicillin and lysozyme were incubated together in a pH-stat at $37^{\circ} \mathrm{C}$ for $48 \mathrm{~h}$. The $\mathrm{pH}$ was maintained at approx. 7.4 but a precipitate that formed tended to block the outlet of the burette. The precipitate (about $3 \mathrm{mg}$ ) was removed and the supernatant fractionated by gel filtration (Fig. 3). The molar proportion of ${ }^{14} \mathrm{C}$ in tube 5 was 1.33 ; the amount of lysozyme was determined by biuret assay, and the basis for the values for the extent of labelling is $14 \mathrm{mg}$ of protein. The molar proportion of penicilloyl groups in tube 6 (measured by penamaldyl assay; Schneider \& de Weck, 1966a) was 1.27. (The median value of the extent of radioactive labelling from five other experiments was 1.3.) Thus both methods indicated the same extent of labelling.

A portion of the labelled lysozyme was reduced and carboxymethylated (Canfield, 1963) in a volume of $1 \mathrm{ml}$, and, after dialysis, the protein was digested with $0.1 \mathrm{mg}$ of trypsin in $1 \% \mathrm{NH}_{4} \mathrm{HCO}_{3}$ at $37^{\circ} \mathrm{C}$ for $4 \mathrm{~h}$.

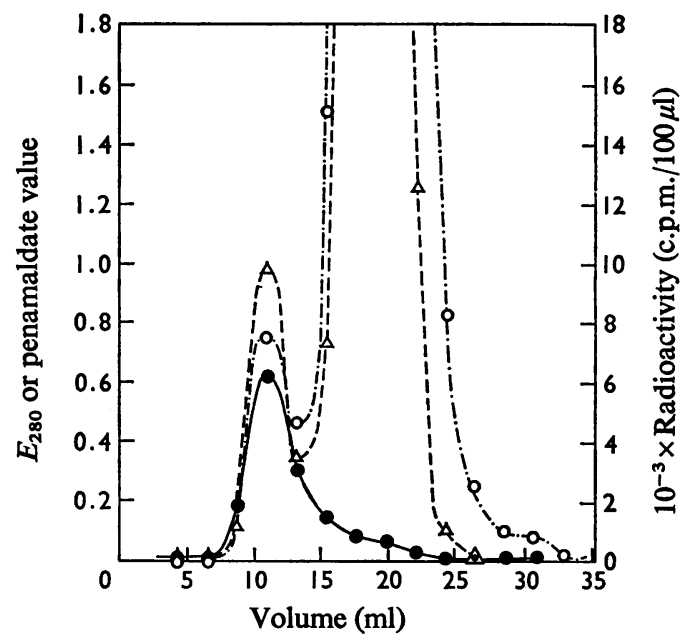

Fig. 3. Gel filtration of reaction mixture of benzylpenicillin and lysozyme

Benzylpenicillin (potassium salt) $(50 \mathrm{mg}$, containing $10 \mu \mathrm{Ci}$ of potassium 6-phylen $\left[1-{ }^{14} \mathrm{C}\right]$ acetamidopenicillanate) and $50 \mathrm{mg}$ of lysozyme in $1 \mathrm{ml}$ of $0.05 \mathrm{M}$-sodium phosphate were incubated at $\mathrm{pH} 7.4$ for $48 \mathrm{~h}$ at $37^{\circ} \mathrm{C}$. The clarified reaction mixture was fractionated on a column $(30 \mathrm{~cm} \times 1 \mathrm{~cm}$ diam.) of Sephadex G-25 with $1 \%$ $\mathrm{NH}_{4} \mathrm{HCO}_{3}$. Fractions of volume $2.2 \mathrm{ml}$ were collected. Radioactivity $(0)$ was determined, penamaldyl assays $(\Delta)$ were carried out to estimate penicilloyl groups and measurements of $E_{280}(\theta)$ were also made. 
Table 2. Radioactive peptides obtained from reaction of $\left[{ }^{14} \mathrm{C}\right]$ penicillin with lysozyme

Peptide $\mathrm{LT}_{1}$ was isolated after tryptic cleavage of reduced and carboxymethylated lysozyme. Peptides $\mathbf{L P}_{\mathbf{1}}-\mathbf{L P}_{\mathbf{3}}$ are samples isolated after digestion with Pronase. The isolations are described in the text. The electrophoretic mobilities refer to $\mathrm{pH} 1.8$ and are relative to serine $(m=1.00)$. The amino acid compositions are given as molar ratios, and the ${ }^{14} \mathrm{C}$ as $\mathrm{g}$-atoms/mol of peptide. Abbreviation: CmCys, $S$-carboxymethylcysteine. The values in column (2)are those calculated for residues $115-125$, and in column (6) those for residues 116-119.

\begin{tabular}{|c|c|c|c|c|c|c|c|c|}
\hline Amino acid & Peptide & ... & $\begin{array}{c}\text { (1) } \\
\mathrm{LT}_{1}\end{array}$ & $\begin{array}{c}\text { (2) } \\
\text { calc. for } \\
115-125\end{array}$ & $\begin{array}{l}\text { (3) } \\
\text { LP }_{1}\end{array}$ & $\begin{array}{c}(4) \\
\mathbf{L P}_{2}\end{array}$ & $\begin{array}{c}(5) \\
\mathbf{L P}_{3}\end{array}$ & $\begin{array}{c}(6) \\
\text { calc. for } \\
116-119\end{array}$ \\
\hline CmCys & & & 0.4 & 1 & & & & \\
\hline Asp & & & 1.6 & 1 & 1.6 & 1.4 & 1.3 & 1 \\
\hline Thr & & & 0.8 & 1 & 1.0 & 1.0 & 0.9 & 1 \\
\hline Ser & & & 0.8 & & 0.5 & 0.5 & & \\
\hline Glu & & & 0.8 & 1 & & & & \\
\hline Gly & & & 1.4 & 1 & 1.0 & 1.0 & 1.1 & 1 \\
\hline Ala & & & 1.1 & 1 & & & & \\
\hline Val & & & 1.1 & 1 & 0.3 & 0.3 & & \\
\hline Ile & & & 0.9 & 1 & & & & \\
\hline Leu & & & 0.6 & & & & & \\
\hline Tyr & & & & & & & 0.3 & \\
\hline His & & & & & & 0.2 & & \\
\hline Lys & & & 0.6 & 1 & 0.4 & 0.5 & 0.3 & 1 \\
\hline Arg & & & 0.7 & 1 & & & & \\
\hline${ }^{14} \mathrm{C}$ & & & & & 0.8 & 0.85 & 0.5 & \\
\hline$m$ & & & & & 0.5 & 0.5 & 0.45 & \\
\hline
\end{tabular}

The digest was fractionated by electrophoresis at pH3.5 followed by chromatography in solvent BAWP. Only one radioactive spot $\left(\mathrm{LT}_{1}\right)$ was detected; its position was close to that of free leucine, which is the $C$-terminal tryptic product (Canfield, 1963), and indeed the peptide $\mathrm{LT}_{1}$ (Table 2) was probably contaminated with leucine. The amount of peptide $\mathrm{LT}_{1}$ was small (a few nmol) but the analysis (Table 2) suggested that this peptide comprised residues 115125 of lysozyme:

\section{Cys-Lys-Gly-Thr-Asp-Val-Gln-Ala-Trp-Ile-Arg}

This result points to reaction at lysine-116, but it leaves other possibilities open.

Several other attempts to purify the radioactive tryptic peptides or peptic peptides were unsuccessful. A more extensive digestion to a smaller peptide seemed more promising. In fact the first experiment along these lines gave mainly a substituted amino acid, namely penicilloyl-lysine. The labelled protein was digested with $1 \mathrm{mg}$ of Pronase/ml of $1 \%$ $\mathrm{NH}_{4} \mathrm{HCO}_{3}$ for $16 \mathrm{~h}$ at $37^{\circ} \mathrm{C}$, and the digest fractionated on a column $(150 \mathrm{~cm} \times 1 \mathrm{~cm}$ diam.) of Sephadex G-25 in $0.5 \% \mathrm{NH}_{4} \mathrm{HCO}_{3}$ [in $10 \%(\mathrm{v} / \mathrm{v})$ propan-2-ol]. The material in the first radioactive peak was fractionated further by electrophoresis at $\mathrm{pH} 1.8$; the main radioactive band ( $m=0.23)$ gave (after treatment with dansyl chloride and hydrolysis) a deriva- tive that was either $\alpha$ - or $\varepsilon$-Dns-lysine; it separated from $\varepsilon$-Dns-lysine on electrophoresis at $\mathrm{pH} 4.5$ and was, as expected for $\alpha$-Dns-lysine, more 'basic'.

Limited digestion with Pronase was thus required. Timed digestions of a portion of labelled lysozyme with $0.17 \mathrm{mg}$ of Pronase $/ \mathrm{ml}$ suggested that incubation for about $1 \mathrm{~h}$ would give the best yield of radioactive material other than large peptides and undigested protein on the one hand, or penicilloyl-lysine (the sole product after $24 \mathrm{~h}$ ) on the other hand. The digest $(1.5 \mathrm{~h})$ was fractionated on a column $(115 \mathrm{~cm} \times 1 \mathrm{~cm}$ diam.) of Sephadex G-25 (in $0.5 \% \mathrm{NH}_{4} \mathrm{HCO}_{3}$ in $10 \%$ propan-2-ol); the first radioactive peak contained relatively high-molecular-weight material, and was redigested (for $4 \mathrm{~h}$ ) and refractionated by gel filtration. The low-molecular-weight peptides were then further fractionated by paper electrophoresis at pH1.8 to give the peptides $\mathbf{L P}_{1}-\mathbf{L P}_{3}$ (Table 2). These appear to be samples of the same tetrapeptide: LysGly-Thr-Asp (residues 116-119). Although none is pure, the impurities in the samples differ. The second two samples $\left(\mathrm{LP}_{2}\right.$ and $\left.\mathrm{LP}_{3}\right)$ were obtained from the redigested material, and it is possible that the variant with slightly different mobility $\left(\mathbf{L P}_{3}\right)$ might have undergone epimerization at C-5, as can happen with penicilloylamides (Levine, 1960; Levine \& Ovary, 1961; Schneider \& de Weck, 1967).

Hence radioactivity has been found $(a)$ in a peptide 

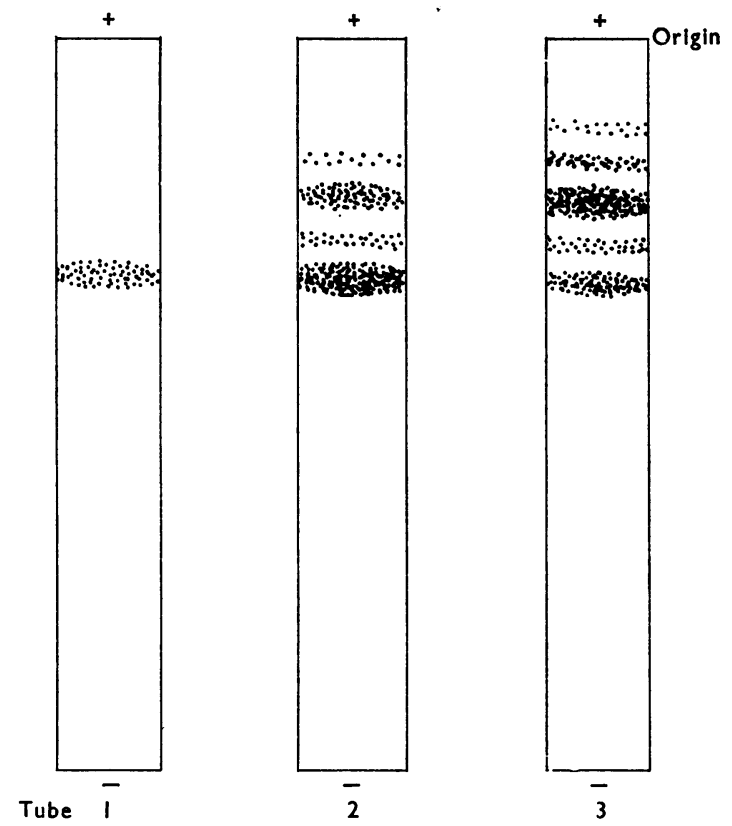

Fig. 4. Gel electrophoresis of reaction mixture of benzylpenicillin and lysozyme

A mixture of $5 \mathrm{mg}$ of lysozyme and $12.5 \mathrm{mg}$ of benzylpenicillin in $0.25 \mathrm{ml}$ of $0.2 \mathrm{M}$-sodium phosphate, $\mathrm{pH} 7.6$, was incubated overnight (tube 2) or for 3 days (tube 3) at $37^{\circ} \mathrm{C}$. The solution was made $7 \mathrm{M}$ in urea, adjusted to $\mathrm{pH} 6$ with acetic acid, diluted with an equal volume of gel buffer (see the Materials and Methods section) and $20 \mu \mathrm{l}$ taken for electrophoresis. Tube 1 contained unchanged lysozyme.

comprising residues $115-125,(b)$ in one comprising residues 116-119 and $(c)$ in a derivative giving only lysine after hydrolysis. Thus the residue attacked by penicillin is lysine-116. This is the only site identified, but whether it is the only site attacked is much harder to say.

\section{Course of reaction of penicillin with lysozyme}

The course of this reaction was studied by gel electrophoresis of the reaction mixture. This method had the advantage that some idea of the complexity of the reaction mixture was gained, and the disadvantage that quantitative information was not obtained. The results (Fig. 4) showed that after reaction for 1 day there were bands in the position of unchanged lysozyme and behind this position; the reaction of penicillin with lysozyme will decrease the net positive charge (at pH6) of the protein. At 3 days, the intensity of the slower band had increased and that of the lysozyme had decreased.

\section{Reaction of cephalosporin $C$ with insulin}

Cephalosporin C $(75 \mathrm{mg} / \mathrm{ml})$ and insulin $(10 \mathrm{mg} / \mathrm{ml})$ were incubated together in $0.05 \mathrm{M}$-sodium phosphate, $\mathrm{pH} 7.4$, in the pH-stat at $37^{\circ} \mathrm{C}$ for $20 \mathrm{~h}$. The gel filtration in $1 \% \mathrm{NH}_{4} \mathrm{HCO}_{3}$ on Sephadex G-25 had to be carried out twice to achieve separation of the highmolecular-weight fraction. A portion $(880 \mu \mathrm{g})$ of the high-molecular-weight fraction was hydrolysed, and the spot of $\alpha$-aminoadipic acid seen on electrophoresis at $\mathrm{pH} 4.5$ of the hydrolysate was comparable in intensity with the spot from $96 \mu \mathrm{g}$ of cephalosporin $C$ treated similarly. Since the molecular weight of insulin is (to a first approximation) ten times that of cephalosporin $C$, this result suggests that there was about one residue of a moiety derived from cephalosporin $\mathrm{C} / \mathrm{molecule}$ of insulin. Control experiments showed that hydrolysis of insulin alone did not give a spot in the position of $\alpha$-aminoadipic acid on electrophoresis at $\mathrm{pH} 4.5$.

The labelled insulin was digested with thermolysin, and compared with a digest of unchanged insulin, but the only identified ninhydrin-positive material present solely in the digest of the labelled insulin was $\alpha$-aminoadipic acid. In another experiment the labelled insulin was digested with Pronase, and the digest examined by electrophoresis at pH6.5. There appeared to be several acidic bands that had partially decomposed and were very streaky; the fastest strong band was refractionated at $\mathrm{pH} 3.5$, but again there appeared to be much decomposition. Apparently identification of the site of reaction will be difficult unless the products can be stabilized.

\section{Discussion}

\section{Extent and selectivity of reaction}

There are two aspects to the subject of the reaction of penicillin with proteins, namely whether reaction occurs at all, and, if reaction does occur, whether some sites are selectively attacked. These aspects are related, and a 'super-reactive' group (Cohen, 1970) will react readily and selectively. However, in the proteins we examined there were no groups that reacted with penicillin at exceptional rates.

\section{Extent of reaction}

The experiments described were carried out with relatively high concentrations $(0.4 \mathrm{M})$ of penicillin, whereas the concentrations of insulin or lysozyme were only a few mM. It is not that a large 'excess' of reagent is necessary but that its concentration must be high for there to be appreciable labelling. This is a consequence of hydrolysis of the reagent. Thus for the simple scheme:

$$
\begin{aligned}
\mathrm{R}+\mathrm{S} \stackrel{k_{2}}{\longrightarrow} \mathrm{P} \\
\mathrm{R} \stackrel{k_{2}}{\longrightarrow} \mathrm{X}
\end{aligned}
$$


where $\mathbf{R}$ and $\mathbf{S}$ stand for reagent (penicillin) and substrate (a site in insulin or lysozyme), and $P$ and $X$ stand for penicilloylated site and penicilloate respectively, then

$$
\mathrm{d}[\mathrm{R}] / \mathrm{d}[\mathrm{S}]=\left(k_{1}[\mathrm{~S}]+k_{2}\right) / k_{1}[\mathrm{~S}]
$$

and so the fraction of protein site labelled, $F$, when all the reagent has been consumed, is given by

$$
F=1-\exp \left(-r_{0} k_{1} / k_{2}\right)
$$

where $r_{0}$ is the initial concentration of reagent (penicillin). The same considerations apply to the labelling of amino groups with dansyl chloride (Gray, 1972). Thus for $50 \%$ labelling of a site, if $k_{1}=$ $3 \times 10^{-2} \mathrm{M}^{-1} \cdot \mathrm{h}^{-1}$ (Schneider \& de Weck, 1968), and $k_{2}=1.4 \times 10^{-2} \mathrm{~h}^{-1}$ (the half-life of benzylpenicillin was found to be about $50 \mathrm{~h}$ ), the concentration of penicillin must be about $0.3 \mathrm{M}$. In fact the extent of labelling of insulin increased from about 0.7 to about 2 groups/molecule as the concentration of penicillin was increased from 0.1 to $0.4 \mathrm{M}$. Although these considerations are over-simplified and approximate, they explain the high concentrations of penicillin used by Schneider \& de Weck (1968) and suggested that we also would have to use high concentrations of penicillin for reasonably efficient labelling of protein sites. The results of Batchelor et al. (1965) are also consistent with these calculations on the reasonable assumption that their extent of labelling was of the order of a few per cent.

The rate of the reaction has not been much studied, but the time-course for the reaction of penicillin with insulin (Fig. 2) is qualitatively consistent with the kinetic scheme given.

\section{Selectivity in reaction of penicillin with proteins}

Of two proteins that have been studied the reaction with lysozyme is apparently more selective than that with insulin. The reaction with insulin at two out of the three amino groups, one $\alpha$-amino (A1) and one $\varepsilon$ amino (B29), is a not uncommon pattern of acylation (Lindsay \& Shall, 1971; Blundell et al., 1972; Brandenburg et al., 1972). With lysozyme, only one site of reaction has been identified, but there may have been reaction at another site as well. The grounds for thinking this are that, although the average extent of labelling was often approximately one group/ molecule, the gel electrophoresis (Fig. 4) suggested that about half the protein had unchanged electrophoretic mobility and so was presumably unchanged lysozyme. This would demand a co-operative process, in which unsubstituted and disubstituted products predominate, and monosubstituted product is scarce. All the lysine residues of lysozyme may be acetylated (Parsons et al., 1969), and it may be significant that all seven amino groups are trinitrophenylated in a process that shows a maximum rate (Freedman \& Radda, 1968). Spectrophotometric estimation of tyrosine (from changes of $E_{292}$ in alkali) did not suggest any modification of tyrosine by penicillin; phenolic hydroxyl groups in low-molecularweight compounds reacted with penicillin at about one-tenth the rate of amino groups (Schneider \& de Weck, 1968), but acetylimidazole (a reagent that resembles penicillin in being an 'activated amide') reacts readily with tyrosine residues (and lysine residues) in lysozyme (Parsons et al., 1969); it is not known which are the amino groups of lysozyme that react with acetylimidazole.

The amino group of lysozyme that reacted with penicillin was lysine-116. The amino group appears 'accessible' (Phillips, 1966; Shrake \& Rupley, 1973), and it may be significant that there is another nearby polar group, namely arginine-112. It seems probable that interaction between these groups could aid the preferential reaction of lysine-116 with penicillin; penicillin reacts about 100 times more rapidly with ethylenediamine than it does with $\varepsilon$-aminohexanoic acid (Schneider \& de Weck, 1966b). Such bifunctional catalysis may often underline enhanced reactivity of a particular group in a protein (Cohen, 1970).

\section{Chemical basis for penicillin allergenicity}

The work described goes some way towards providing a firm basis for the nature of the 'major antigenic determinant', the penicilloyl group (I), where $\mathrm{R}^{\prime}=-\mathrm{NH}\left[\mathrm{CH}_{2}\right]_{4} \mathrm{CH}_{-}^{-}{ }_{-\mathrm{CO}-}^{-\mathrm{NH}-}$. Reaction with either an $\alpha$-amino group at the end of a polypeptide chain, or an $\varepsilon$-amino group of lysine, or both, has been demonstrated. This is indeed what had commonly been supposed, but it had never been shown. The next stage in the analysis of allergenicity demands knowledge of which proteins react with penicillin in vivo, and this knowledge is lacking.

Attempts to follow up previous work (HamiltonMiller \& Abraham, 1971) on the determinants derived from cephalosporins have not been successful; all that can be said with certainty is that after incubation of insulin with cephalosporin $C$ the high-molecular-weight fraction releases $\alpha$-aminoadipic acid on hydrolysis.

The support of the Medical Research Council is gratefully acknowledged, as is the technical assistance of Mrs. C. Moss and Miss R. Sammons. We thank Glaxo Research Laboratories and Novo Terapeutisk Laboratorium for gifts, and Professor E. P. Abraham, C.B.E., F.R.S., and Dr. L. N. Johnson for helpful discussions.

\section{References}

Batchelor, F. R., Dewdney, J. M. \& Gazzard, D. (1965) Nature (London) 206, 362-364

Blundell, T., Dodson, G., Hodgkin, D. \& Mercola, D. (1972) Adv. Protein Chem. 26, 279-402 
Brandenburg, D., Gattner, H. G. \& Wollmer, A. (1972) Hoppe-Seyler's Z. Physiol. Chem. 353, 599-617

Brown, H., Sanger, F. \& Kitai, R. (1955) Biochem. J. 60, 556-565

Browne, C. A. \& Waley, S. G. (1974) Biochem. J. 141, 753-760

Canfield, R. E. (1963) J. Biol. Chem. 238, 2691-2697

Cohen, L. A. (1970) Enzymes, 3rd edn., 1, 147-211

Corran, P. H. \& Waley, S. G. (1974) Biochem. J. 139, 1-10

de Weck, A. L. \& Schneider, C. H. (1969) Curr. Probl. Immunol. Bayer-Symp. 1 st pp. 32-46

de Weck, A. L., Schneider, C. H. \& Gutersohn, J. (1968) Int. Arch. Allergy Appl. Immunol. 33, 535-567

Freedman, R. B. \& Radda, G. K. (1968) Biochem. J. 108, 383-391

Gray, W. R. (1972) Methods Enzymol. 25, 121-138

Hamilton-Miller, J. M. T. \& Abraham, E. P. (1971) Biochem. J. 123, 183-190

Heilmann, J., Barollier, J. \& Watzke, E. (1957) HoppeSeyler's Z. Physiol. Chem. 309, 219-220

Idsoe, O., Guthe, T., Willcox, R. R. \& de Weck, A. L. (1968) Bull. WHO 38, 159-188

Johnson, L. N. (1967) Proc. R. Soc. London Ser. B 167, 439-440

Leggett-Bailey, J. (1967) Techniques in Protein Chemistry, p. 341, Elsevier Publishing Co., London

Levine, B. B. (1960) Nature (London) 187, 939-940

Levine, B. B. (1962) J. Med. Pharm. Chem. 5, 1025-1034

Levine, B. B. \& Ovary, Z. (1961) J. Exp. Med. 114, 875-904

Lindsay, D. G. \& Shall, S. (1971) Biochem. J. 121, 737-745
MacLaren, J. A. \& Sweetman, B. J. (1966) Aust. J. Chem. $19,2355-2360$

Miller, J. C. \& Waley, S. G. (1971) Biochem. J. 122, 209218

Moon, K., Piszkiewicz, D. \& Smith, E. L. (1973) J. Biol. Chem. 248, 3093-3103

Nakken, K. F., Eldjarn, L. \& Pihl, A. (1960) Biochem. Pharmacol. 3, 89-100

Offord, R. E. (1966) Nature (London) 211, 591-593

Parsons, S. M., Jao, L., Dahlquist, F. W., Borders, C. L., Groff, T., Racs, J. \& Raftery, M. A. (1969) Biochemistry 8, 700-712

Phillips, D. C. (1966) Sci. Am. 215, 78-90

Rüegg, U. Th. \& Rudinger, J. (1974) Isr.J. Chem. 12, 391401

Schneider, C. H. \& de Weck, A. L. (1966a) Helv. Chim. Acta 49, 1689-1694

Schneider, C. H. \& de Weck, A. L. (1966b) Helv. Chim. Acta 49, 1695-1707

Schneider, C. H. \& de Weck, A. L. (1967) Helv. Chim. Acta 50, 2011-2018

Schneider, C. H. \& de Weck, A. L. (1968) Biochim. Biophys. Acta 168, 27-35

Shrake, A. \& Rupley, J. A. (1973) J. Mol. Biol. 79, 351-371

Sluyterman, L. A. AE. (1955) Biochim. Biophys. Acta $17,169-176$

Smith, H. \& Marshall, A. C. (1971) Nature (London) 232, 45-46

Stewart, G. T. (1973) Annu. Rev. Pharmacol. 13, 309-324

Waley, S. G. \& Watson, J. (1953) Biochem. J. 55, 328-337 